\title{
CONSTRUCTING FEMINISTS MAPS OF GOIANIA CITY
}

\author{
Talita Cabral
}

p. $30-46$

\section{Magazine}

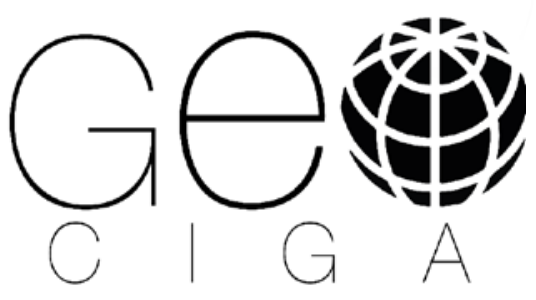

Eletronic Magazine:

Tempo - Técnica -

Território, V.7, N.2 (2016),

30:46 ISSN: $2177-4366$

DOI: https://

doi.org/10.26512/

ciga.v7i2.19361
How to quote this article:Cabral, T. CONSTRUCTING FEMINISTS MAPS OF GOIÂNIA CITY. Eletronic Magazine : Tempo - Técnica - Território, v.7, n.2 (2016), p. 30:46 ISSN: 2177-4366. DOI: https://doi.org/10.26512/ciga.v7i2.19361

Available in: http://periodicos.unb.br/index.php/ciga

This work is licensed under a Creative Commons License Attribution - Non-Commercial 4.0 International. 


\title{
CONSTRUCTING FEMINISTS MAPS OF GOIÂNIA CITY.
}

\author{
Talita Cabral \\ Doctor in Geography by the Federal University of Goiás. Geographer in the Board of Urban \\ Information and Geo processing of the Municipal office of urban planning of Goiânia. \\ Address: Quadra 22 - Lote 49 - Setor Leste, Gama - DF. CEP: 72460220 \\ E-mail: talita.geo@gmail.com \\ Funding Body of the research: Coordenação de Aperfeiçoamento de Pessoal de nível superior
} (CAPES).

\begin{abstract}
RESUMO: Objetivo é construir mapas das ações feministas da cidade de Goiânia (GO). A metodologia adotada utiliza-se das narrativas de lideranças, por meio de entrevistas semiestruturadas com treze feministas e das técnicas de mapeamento participativo. Foram mapeados os locais e trajetos considerados importantes para as lutas das mulheres. Os pressupostos teóricos são baseados em leituras sobre cartografias e mapas participativos, sociais e/ou culturais. As atuações feministas são pensadas de maneira distinta em cada região da cidade. As mulheres consideram as diferentes regiões político-administrativas para a construção de suas atividades, assim como as diferenciações entre centro e periferia. Existem locais e regiões da cidade onde apenas alguns grupos específicos feministas atuam e outros, onde todos eles estão presentes, a exemplo, do Setor Central. Os mapas evidenciam os locais e percursos das ações das entrevistadas e seus coletivos e possibilitam iniciar uma reflexão sobre a relação entre as questões de gênero e a cidade.
\end{abstract}

Palavras-chaves: mapa; cartografia; grupos feministas; feministas; cidade.

\begin{abstract}
The goal is to construct maps of feminists actions in Goiania(GO). The chosen methodology use stories of leadership, by means of semi structured interviews with thirteen feminists and the interactive mapping techniques. Were mapped the places and routes considerate important in the woman fight. The theoretical suppositions are based in cartographic readings about cartography and interactive maps, social and/or cultural. The feminists actions are thought in a different way in each area of the city. The woman considerate the different political administrative areas to the construction of their activities, as the variations between center and periphery. There are places and locations of the city where only a few specific feminists groups act, and others where all of them are attending, as an example, the Central Sector. The maps highlight the places and paths of the actions of the interviews and their unions make it possible to begin a reflection about the relation between gender issues and the city.
\end{abstract}

Keywords: map; cartography; feminist groups; feminists; city.

RESUMEN: El objetivo es construir mapas de las acciones feministas de la ciudad de Goiânia (GO). La metodología adoptada se utiliza de las narrativas de liderazgos, por medio de entrevistas semiestructuradas con trece feministas y de las técnicas de mapeo participativo. Se asignaron los 
lugares y trayectos considerados importantes para las luchas de las mujeres. Los presupuestos teóricos se basan en lecturas sobre cartografías y mapas participativos, sociales y / o culturales. Las actuaciones feministas son pensadas de manera distinta en cada región de la ciudad. Las mujeres consideran las diferentes regiones político-administrativas para la construcción de sus actividades, así como las diferenciaciones entre centro y periferia. Hay lugares y regiones de la ciudad donde sólo algunos grupos específicos feministas actúan y otros, donde todos ellos están presentes, a ejemplo, del Sector Central. Los mapas evidencian los lugares y recorridos de las acciones de las entrevistadas y sus colectivos y posibilitan iniciar una reflexión sobre la relación entre las cuestiones de género y la ciudad

Palabras-clave: mapa; cartografía; grupos feministas; feministas; ciudad.

\section{INTRODUCTION, GOAL, METHODOLOGY AND THEORETICAL DISCUSSION.}

The article is a result of a doctorate research, conclude in December 2016 (MACHADO, 2016) about feminists cartographies of the city from the ownership of Goiânia's urban space processes accomplished by different activists woman.

Cartography is a language, correspondent to the organization of signs in the construction of a message. It also constitute a manner of representation of the space and the spatial processes. The map is a cartographical representation of the spatiality of the phenomenon. It is a social construction, with the subject intent to recognize an order and try to pull off a meaning.

Martinelli (1999) says that in any culture, maps are manipulated forms of knowing, in which the images are loaded with value. When are asked about which are the maps that are most accessible, the most used to the construction of public policies and who are the subjects that construct these maps, one must have in mind the relations between power and subject in the process of mapping.

The map, product derived from cartography, is a representation of space and comprehend the relations of power constructed in the process of mapping. The maps, throughout their codes, convention and organization and procedures organization and taxionomy operate as a technology of power. They are selective and have the propose to spread and reinforce the ideologies that, for a long time, were dominant. Santos (2010) complete this point of view saying:

The diffusion of a technique and Cartesian vision of the world, p.ex., by the form as we teach cartography. In a form of spatial representation, she is transformed in a only way of spatial expression in the world, truly standards of natural and social existences, resulting in the possibilities of technical rationality underlying the process of map elaboration- that are, so to speak, limited by this rationality of the scientific occidental way of seeing the world, of expressing the space references, of time and the social and social experiences. This way of working and teaching schooling cartography give the official maps a nature of expression of the truth that

Electronic Journal: Time - Technique - Territory, V.7, N.2 (2016), 30:48 ISSN: 2177-4366 
is a powerful instrument of power through the production of non existing of forms and relations to the world. (SANTOS,2010, p.150)

Opposing to the way of comprehend the map exposed above by Santos(2010), it is intensifying in Brazil the number of social and cultural groups in the field, in forest and in the city that seeks the cartographic tools to accomplish their own mapping. From the moment that the subordinated social and cultural groups started to appropriate themselves of the map production, through the inclusive and the social cartography, new territorialities emerge and are recognized. The subject of this group map, confirming their specific territorialities.

The social cartography goals diverse and the used methodologies too. One of the goals is to indicate, qualify and discuss the lived conflicts, which are the "aggressions" and the collectives subjects involved. In addition, highlight the negative impacts of the activities and their locations.

The participative cartography emerge in a context characterized by a displacement of the exclusiveness and incontestability of the official cartography of the state, Cartesian and positivist, to a growing number of many practices and experiences that gives another meaning to cartography.

Massey(2008) presents the vision of Huggan(1989) saying that the new forms of mapping (also from the inclusive cartography, social and/or cultural) can at the same time represent strict attitudes of the past (as the location of the events and coordinates $\mathrm{x}$ and $\mathrm{y}$ that are still important and widely used. To Massey:

In these projects, maps can in the same time deconstructed and, reconstructed under a way that challenges the claim of uniqueness, stability and closing that characterize our notion (and, surely, in most cases it is the goal) usually the cartographic representation. (2008, p. 163)

What happens in the production of those maps are re imaginations of the possibilities of mapping: "It is the improvement of the criticism of the maps as "technologies of power" to impose our comprehension on the proper form of the map" (MASSEY 2008, P.164). This forms of mapping point out the multiplicity and has as an objective disrupt the classic occidental map, and his unique consistency when pointing the "blind spots" (p.164) and the "lapses"(p.164) brought by them.

Massey(2008) stated that even if denouncing the blind spots and presented in the traditional occidental cartography, this cartography stays "Inside the imagination of the surface" (p.165). Which means "imagining the space being mapped- that is a space of simultaneity- as the product of horizontal overlap, instead of a coexistence plain contemporary and in duty."(p.165). When the mapping take place "we do not realize the ruptures of space, the encounter with the difference $\neg$ (p.165). The maps are limited and brings a delimited cut out of time and space, as they depend on the experience, memory and action with mapped events held by who build them. 
Despite the importance of the ownership of the cartography for a great number of people and social groups, especially from the inclusive cartography, to Acselrad (2010),however, it is born marked by ambiguity and establish critical postures in face of the process of mapping is essential. In the last decade context in which become very common the action of inclusive mapping encouraged or promoted by different NGO (Non governmental organization), multilateral agencies of development and companies, and in a context of territorial disputes, the author states:

Constructed to give word to the basic communities and underprivileged groupsintegrating, moreover, according to some people, a territorial project of political counter culture- its accomplishment show itself as dependent to the structure of power in witch it is established. In the broad aspect of the world known experiences, we can see that they can be associated to the identity and territorial aspecs of subordinated groups, that being, with the cognitive construction of the rational management of he natural resources to mechanisms of conflict socioterritorial and environment explanations or other forms of anticipations mechanisms to the purpose of territorial state control. (ACSELRAD, 2010, p. 9 e 10)

For this reason, it is important that the subjects in the inclusive mapping process question constantly: to whom and to what the information will assist?

The increase of the usage of the inclusive cartography, social cartography or cultural cartographic resulted in numerous works in the geography areas, anthropology and other. In the term of 1992-2010 there were experiments Social cartography and inclusive mapping in all regions of Brazil (ACSELRAD, 2010). In the surveys held by Acselrad(2010), the State of Goiás, together with the Federal District, Rio Grande do Norte and Sergipe were the only ones without records of these experiences.

The goal of the article is to construct maps of the feminists acts in the city of Goiânia. The methodology adopted uses the narratives of leadership, by means of semi- structured interviews with thirteen feminists and the inclusive mapping. The places and routes considered important to the women's fights were mapped, they have different timing (past, present, future) and spatialities (temporary, fixed and fluid).

In the first mapping, it was used an existing cartographic base (with limit of neighborhoods, squares, streets and parks), on a scale of Goiânia city. It was included in this informational base (part of it) the actions accomplished in the city by the interviewed feminists women and their collectives. $^{1}$

The first limitation of the maps appear in the process of selection of the interview during the interview period, for they depend on the flow of memories and the moods of the interviewees. The

\footnotetext{
To the development of the map it was used, the free program of geo- processing QGIS(preciously known as "Quantum GIS"), that is a free/open source software, cross-platform of a geo reference system (GIS) that provides the view, edit and analysis of geo-referenced data.
}

Electronic Journal: Time - Technique - Territory, V.7, N.2 (2016), 30:48 ISSN: 2177-4366 
second limitation was the one of the experiences and perceptions of the researcher with the interviewed and the groups of which they were part of. It is not possible to experience all the meetings and demonstrations that happened during the research, because the groups actions are many and not everything that happened in the city, were known. The maps were produced with the objective of construct, partly, the visibility of the feminists actions in different expressions in the city of Goiânia.

So that the maps were recognized among the interviewed, after all the steps of the mapping mentioned above, were proposed meetings with all the women, called of "Coffee with the feminists".

In the first meeting, after a presentation and explanation about the research and the printed maps in different sizes, were made the following questions to the woman attending: If they would change the symbologies and the colors chosen by the researcher? Since the map started from different people and collectives, if would add places and locations of conflicts and coalitions among them? They would have, thus, symbologies of tensions? Should they add more points and/ or important routs or change something in the maps? Moreover, last of all, how the maps could be used as a tool to the feminists fights in town?

After the meeting, were added and updated some points and routes in the maps. As some symbologies and subtitles. When asked about some possible locations of conflicts between them and their groups, the women decided together not to emphasize them, arguing that the maps would be accessed by different people and the intent was to show the alliances and not the conflicts, despite the fact that they exist.

In the meeting, the interviewed said that the map would be used as a tool to: strengthen the feminists moves in town by showing and locating the actions; showing the women the differences existing among the feminists actions and their spatialities accordingly the characteristics of the groups and the militants; knowing the operations of other feminists and groups in Goiânia; bring the discussions about the importance of thinking spatially and their actions.

\section{Results: Mapping the city of Goiânia:}

Founded in 1933, the city of Goiânia has -accordingly to IBGE in 2014- approximately 1.412.364 inhabitant and with a metropolitan region composed by twenty municipalities (State complementary law number 78, 25/03/2010), in which Aparecida de Goiânia, Senador Canedo and Trindade are the closest and most populated. The capital city center, correspond part of the initial plan of the city, host services such as: the public and private, as the seat of the political power of the state, hotels, commerce and some parks. Comparing to other Brazilian cities, it is not noticeable the Electronic Journal: Time - Technique - Territory, V.7, N.2 (2016), 30:46 ISSN: 2177-4366 
prevailing function and the use of feminism and/or feminist. The image 1 corresponds to the map of the location of the state of Goiás and the Goiânia city.

Image 1. Map of the location of Goiânia city, - Goiás, Brazil. Source: Cartographic Base: IBGE ,2010.

The feminists movements in Goiás (Brazil) come up in the 80's with the formation of institutions of woman in Goiânia, as examples the Group Eva de Novo (1981), Centro Popular da Mulher em Goiás (1987),and, later, in the 90's, black women start's their organizations: Association Pérola Negra(1993), Malunga (1999) and Dandara do Cerrado (2002).

During the interviews, the women brought to us the locations in the city that they consider in some form and time important to feminism, experiences, fights, visibility and to the ephemeral spatialization or not of he activities of the groups that they are part of. The image 2 corresponds to the actions that happened during the research, in the so called present time (period between the years 2013 to 2015) and are mapped too the past actions (between the years of 1985 to 2013) and future (after 2015). ${ }^{2}$

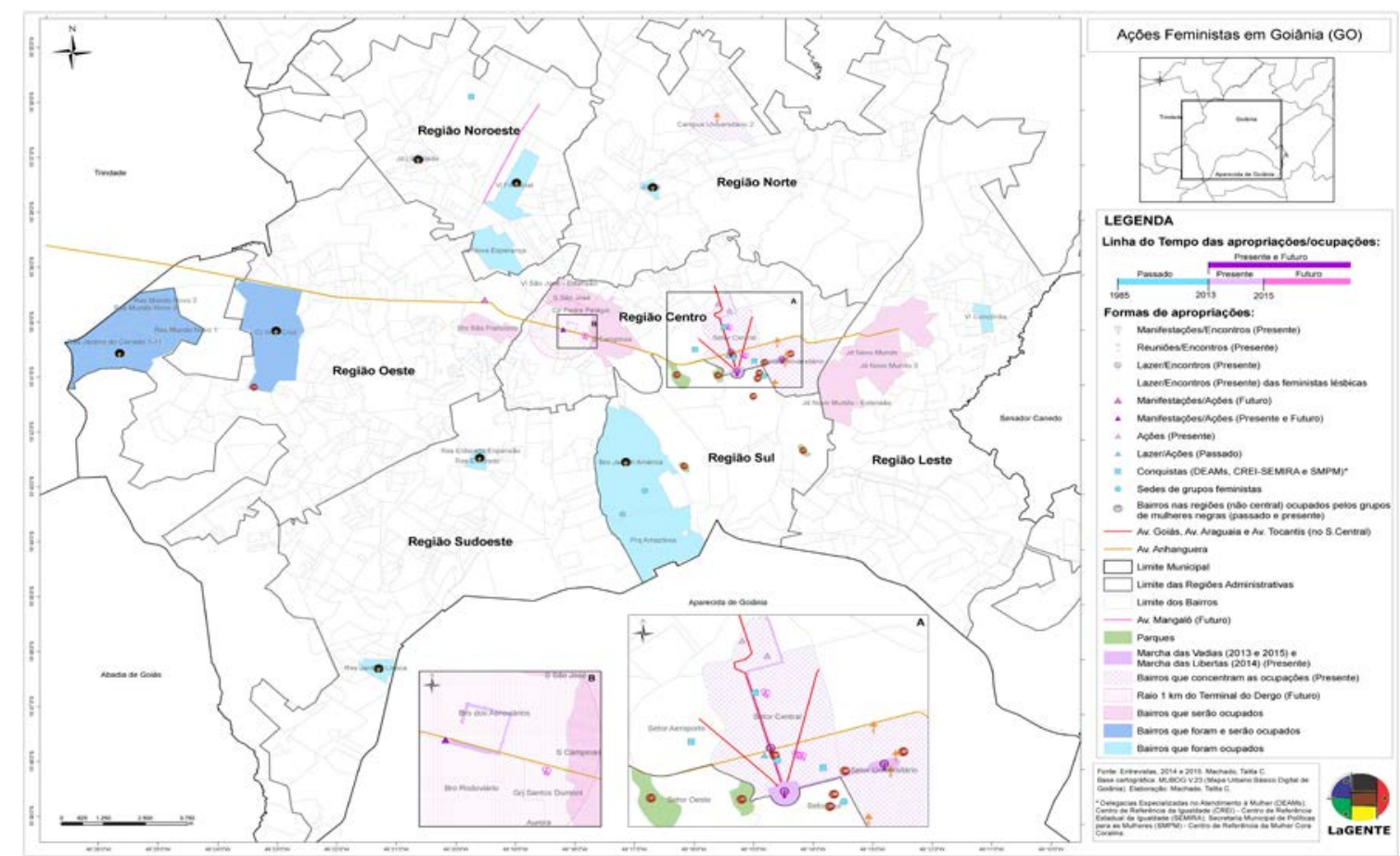

Image 2 Feminists Actions in Goiânia (GO).

Source: MACHADO (2017, P.115)

Years of creation of the Centro Popular da Mulher em Goiás (CMP), whose group is the oldest among the ones the interviewed participate.

Electronic Journal: Time - Technique - Territory, V.7, N.2 (2016), 30:48 ISSN: 2177-4366 
The board presents some symbologies used in the maps and the explanation of the choice made by the women and their meaning.

Board 1: Symbologies used in the maps.

Source: Interviews 2014-2015 and Meeting "Café com cartografias feministas", 2016.

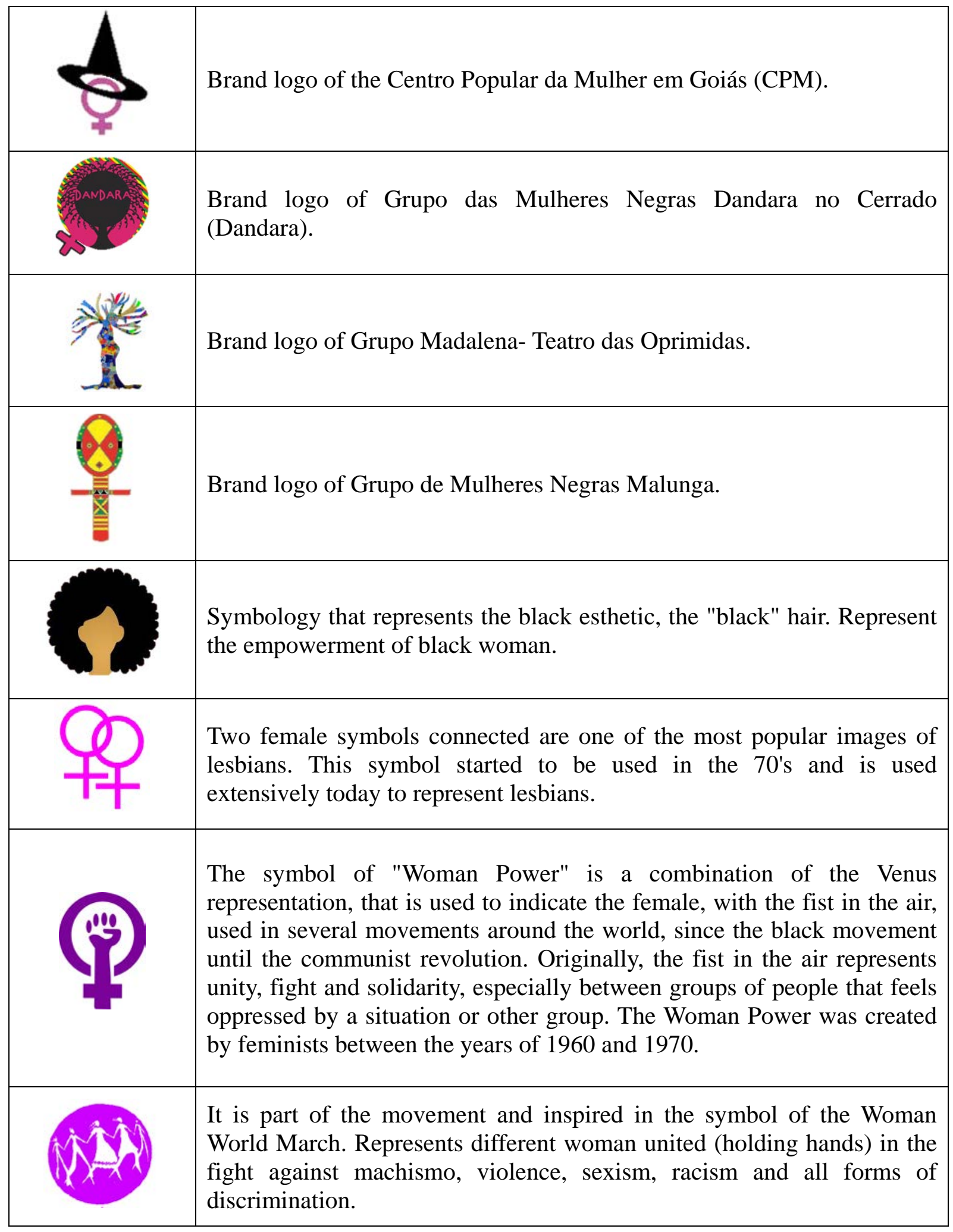

Electronic Journal: Time - Technique - Territory, V.7, N.2 (2016), 30:46 ISSN: 2177-4366 
One of the boundaries of the map (image 2) corresponds to the choice in municipal scale, because the urban ownerships of some interviewed people and their groups surpass the boundaries of the city and expand themselves to the metropolitan region. Locations in the municipality of Aparecida de Goiânia, located south and connected with the urban area of Goiânia, are appropriated by some feminists and their groups and are seen by them as peripheral.

The women consider the organizational logic of the city in different regions politicaladministrative and their specificities to plan and organize their actions (individuals and/or collectives), as the distinction between center and periphery. Following it will be presented some of the actions that happen in each area of Goiânia.

\section{The feminists' actions in the different areas of the city.}

The planning bodies already established, throughout the history of the city, various ways of regionalization of Goiânia. The last regionalization established by the city hall and present in the annual statistic of Goiânia (2012) reallocate the city in seven areas: center or central and Campinas; east; south; west; southeast; north and northwest. This was the regionalization used in the construction of the image $2 .^{3}$

The image 3 below is a cutout of the map of the image 2 (with some extra information) and corresponding to the feminists actions held in the central area of the city.

In the central region, the Central Area and the University Area were the neighborhoods mentioned by the women as the important ones. They were brought up as essential locations for (militant) encounters and leisure among the youngest and most academic feminists. The Central Area (or city center) was raised by all the interviewed as important to give visibility, through the media and the people who are passing in that place, to the manifestations of the groups.

The squares located in these sectors were brought up as important places, mainly the Civic Square, the University Square and the Bandeirantes Square. These three places where, historically, of great circulation, of political mobilization and that can have the presence of the media, concentrate some manifestations. The paths that intersect the three squares are of fundamental importance to the feminisms constructed by women.

Square Bandeirantes nowadays is no longer a square, but rather a crossroad between two main avenues of the city, Avenue Anhanguera and Avenue Goiás. 


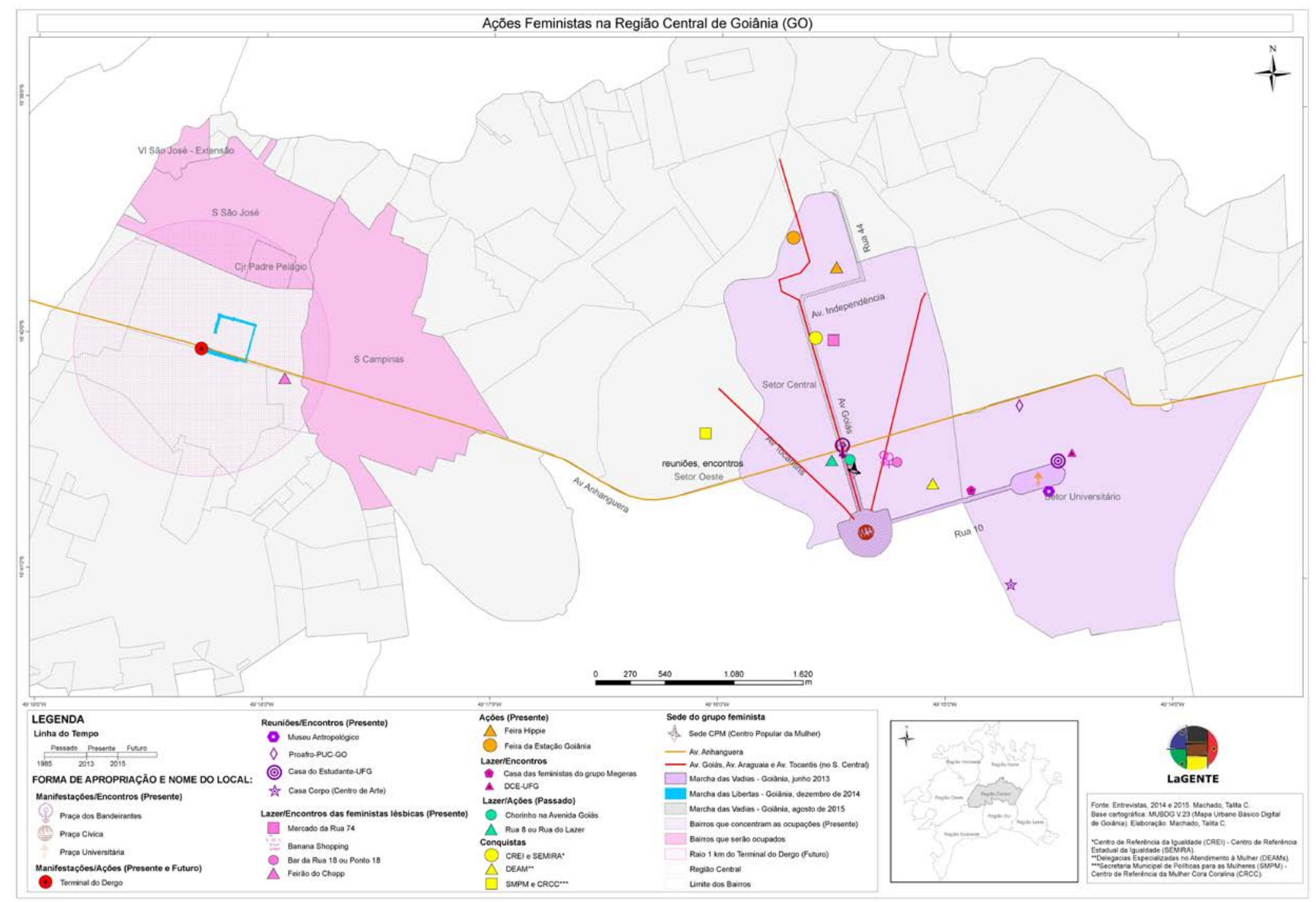

Image 3. Feminists action in the central Area of Goiânia(GO).

Source: MACHADO (2017, p.128)

Electronic Journal: Time - Technique - Territory, V.7, N.2 (2016), 30:46 ISSN: 2177-4366 
It is historically a place of social movements and protests in Goiás. Although it no longer exists as a square, Square of Bandeirantes is still the agora of social movements; it is an important place for feminisms. The choices of the locations for all sorts of manifestations and gatherings among feminists in the central city are political and oriented.

The Civic Square is between Goiás, Tocantins and Araguaia Avenues, and it is where the Pedro Ludovico Palace and much of the state administrative structure are located. Almost all walks, manifestations of feminist groups, leave or pass through this square.

The street markets in the central region, mainly the Hippie street market and the street market of the Station, were brought up in a different way by the interviewed. Some have not brought them as places of great importance for the feminist actions that already take place. For them, the street markets are places that do not function as a place of manifestation. In contrast, black feminist women's groups see street markets as living spaces among black women and are said to be an important place to be appropriated by them.

Squares are places of announcement, of communication, of passage, and especially of experiences, such as during the encounters that take place in them, for example, feminist exchanges and picnics, the majority of participants being young women and / or having some relation with the University.

Feminists, especially lesbians and bisexuals, have brought in places, such as the Market of street 74 (or Popular Market), Feirão do Chope, the Bar at Street 18 (or Point 18) and Banana Shopping, all in the central area, as important places for their moments of leisure and for the collective occupation of women. These are places where they feel good about their sexualities and other identities. $^{4}$

The streets of the central region were brought up by the women as important and some of them have already been places of feminist experiences, such as street 8 and the Grande Hotel Vive the Choro (known as Chorinho), of the Municipal office of Culture of Goiânia, which happened on Avenue Goiás, both in the Central Area.

Street 8, also known as Street of leisure, appeared in the speeches of feminists who were between 44-67 years of age. This place was intensely occupied by them, mainly in the decades of 1980, 1990 and 2000:

The headquarters of some feminist groups, located in the central region, were brought as important achievements of the movements, such as the CPM (Centro Popular da Mulher); the Fórum Goiano de Mulheres and the Assessoria Municipal da Mulher. In these places the feminist formations, the experiences and the constructions of feminisms in Goiânia occur and / or occurred.

\footnotetext{
It is a LGBT place ( Lesbian, Gays, Bisexuals and transsexuals) of nocturnal attendance placed in a peripheral area, that exists for more 10 years. (HAMMES, 2015)

Electronic Journal: Time - Technique - Territory, V.7, N.2 (2016), 30:46 ISSN: 2177-4366
} 
The sites constituted from the feminist struggles in the city were also mentioned, mainly by women between 44-67 years of age who participated in these achievements, such as the Centro de Referência da Igualdade (CREI) of the Secretaria Estadual da Mulher, the Desenvolvimento Social, da Igualdade Racial, the Direitos Humanos e do Trabalho (SEMIRA), the Delegacias Especializadas no Atendimento à Mulher (CEVAM) and the Specialized Delegations for Women's Assistance (DEAM), one located in the Central Area and the other in Jardim Curitiba II (in the northwest region).

Women take into account the differences between center and periphery to carry out their actions. It is important to note that there are also segregated areas in the central and southern regions of Goiânia. ${ }^{5}$

Brazilian cities had their urban structures oriented by the center-periphery relationship. Whose central areas were equipped with better infrastructure and the periphery was seen as residential use of the population with lower income level. However, the changes that have been happening in cities, often driven by real estate and land interests, have also transformed the center and the periphery structure.

The term periphery is used not only in the sense of localization, but social, designating neighborhoods in which the basic services (light, water, sewage, pavement, transportation, school, medical service station) are absent, a situation also found in the "center", that is, in pockets of poverty, slums or subnormal clusters ", According to the IBGE:

(...) can meet the criteria of urbanization and / or precarious standards of essential public services, in the following categories: invasion, irregular or clandestine allotment, and areas invaded and irregular and clandestine subdivisions regularized in a recent period. (IBGE, 2010, p.19).

Villaça (2001) states that one of the most striking features of Brazilian metropolis is the spatial segregation of social classes in distinct areas of the city (not necessarily in geographically peripheral areas). The differentiation between the neighborhoods refers to the profile of the population, such as urban characteristics, infrastructure, conservation of public spaces and equipment, etc.

The DERGO Terminal (Department of Road and Road), located in the former region of Campinas and today the central region, is seen by women as a peripheral location in the center. It is located near neighborhoods that have many "subnormal clusters" (IBGE, 2010, p.19). The area near the DERGO is known as one of the largest prostitution zones in Goiânia, where there are different

\footnotetext{
"[...] segregation is a process where different classes or social classes tend to increasingly focus on different general regions or neighborhood assemblies of the metropolis. " (VILLAÇA, 2001, p. 142, grifo do autor).

Electronic Journal: Time - Technique - Territory, V.7, N.2 (2016), 30:46 ISSN: 2177-4366
} 
sex workers, most of whom are from the lower class and over 35 years of age and the elderly can be found between the ages of 60 and 70 . And it is, at the same time, an area where many women are raped and murdered in the city.

The DERGO Terminal was brought as an important place for the actions of the movements. In an attempt to expand demonstration sites beyond the Central and University Sector, the Terminal and the area around them were brought as "problematic" places regarding gender and sexuality issues and that require an important role of the groups.

In 2014, the third March of the bitches (marcha das Vadias) in Goiânia, called in that year of March of the Libertas and for the first time the place chosen for the concentration was the Terminal of the DERGO. The change of the name of the March took place after several discussions between the participants with the aim of being closer to the demands of the professional women of the sex of that region. This exemplifies the processes by which some feminist groups in the city pass, in spatially and strategically thinking other places for actions and appropriations in the urban space.

For academic and younger women, the achievements should advance to the outskirts of Goiânia (northwest, east, west and southeast). Although violence against women is everywhere, they believe that feminist movements should now prioritize the peripheral inhabitant(s).

In Figure 2, it is observed that the neighborhoods and places where they will be occupied in the future, through actions of the feminist groups linked to the academy, are near or are cut down by the Avenue Anhanguera or Eixo Anhanguera. These neighborhoods and places were brought by women who they travel through them daily and / or experience them, women who live in peripheral areas of the city and who use the Eixo to move in the city, that is, correspond to the daily routes of some interviewed women. ${ }^{6}$

The most peripheral neighborhoods in the west, east and central regions, such as Jardim do Cerrado 1 to 11, Residencial Mundo Novo 1 to 3, Conjunto Vera Cruz, Setor São José, Vila São José Extension, Conjunto Pelagio, Setor Campinas, Bairro São Francisco and Jardim Novo Mundo and the Padre Pélágio Terminal (Bairro Ipiranga and Bairro Capuava), highlighted in Figure 2, were mentioned by women as strategic for future occupations of feminist movements. In these neighborhoods, the population is mostly black and has low incomes, according to the 2010 Census (FERREIRA, 2014).

While young women linked to academic feminist movements are initiating the discussion about expanding their actions to the periphery of the city, and this discourse is more present in the

\footnotetext{
The Eixo Anhanguera is the name given to one of the aisle of an exclusive public transport, in the BRT mode, located in Goiânia. It has $14 \mathrm{~km}$ of extension, link the extremes east and west, through the Avenue Anhanguera, one of the most important Avenues of the city. Over its route, between Terminals Padre Pelagio (Ipiranga Neighborhood) and Novo Mundo (Novo Mundo Sector), crosses three more integration terminals (Terminal DERGO, Terminal "A" Square and Square of the Bible), that make the connection with a great part of the other regions of Goiânia.

Electronic Journal: Time - Technique - Territory, V.7, N.2 (2016), 30:46 ISSN: 2177-4366
} 
speeches of women who live in and / or originate from peripheral locations and who are in university, some feminists aged 44-67, said that past actions, organized by the groups they participated in, focused on the more peripheral neighborhoods. Some interviewees said that meetings and actions were held in the most peripheral neighborhoods of the city, and this was a practice of several groups (feminists, left wing, etc.) started before 1984 because of the existence of the Military Dictatorship. For during the dictatorship (1964-1984), the center of the city was intensively monitored by the military, which did not allow the meetings and meetings of many social movements.

Black women's groups have, since their inception, been active on the periphery. They were created thinking the appropriations of the periphery, through experiences and various projects.

Other places mentioned by feminists were the schools of the peripheries and the houses of women, seen as important places for living among them.

The fairs, both in the central and peripheral regions of the city, were brought as relevant sites. In the fairs located in central areas, the target audience are the marketers, and in the periphery, it is mainly the women who make the street markets. The center street markets, which were brought by feminists, predominantly market of clothing, footwear and accessories. On the other hand, the markets in the peripheral areas, where the feminists groups of black and/ or women of the periphery sell ,mainly, food (fruits, vegetables, etc.).

In the southern region, young women and academics brought environmental parks, with a large circulation of people on weekends, which are: Buritis Park (West Sector), Park Lagoa das Rosas (West Sector), Park Vaca Brava in Bueno) and Flamboyant Park (Jardim Goiás). These are the places where feminist urban interventions take place that are moments of encounter between women and the various groups and take place in public spaces of the city. During the speeches, the wheels of conversations, workshops, picnics, trade shows, plays etc., always with themes focused on women.

The headquarters of the group Madalenas and black women Malunga and Dandara do Cerrado, located in the southern region, were brought by the interviewees as places of feminist references.

In the central region, feminist appropriations are carried out more intensively in pubic spaces, such as the square, streets and environmental parks. In the periphery, the spaces of houses, schools and residents' associations are the most important places to make appropriations. This tells us about the difference in the uses of public spaces in the center and in peripheral areas.

In the northern region, the Federal University of Goiás was present in the speeches of the interviewees as an important place for feminist actions in order to be present and active, both 
organized in groups and collectives or through their individual trajectories, such as students, teachers, etc. The UFG is seen as a place where feminist achievements are present, and as the home of social movements, as well as giving physical support to the groups to hold meetings, meetings, workshops, etc., which take place in a intermittent, temporary and mobile within the university.

Some sites mapped in Figure 2 were presented and discussed, and it was concluded that there are places where only a few specific feminist groups act (e.g., black women working in peripheral regions) and others where all are present, the Central sector).

\section{Acknowledgments}

The maps resulted from this work show the locations and paths of the actions of the interviewed and their collectives in the city and enable a reflection on how feminists experience these places and organize their actions.

The importance of this research corresponds to the non - dominant mapping in the present studies in urban geography and in the planning and studies about the city. It brings out "the blind spots "(MASSEY, 2008, p.164) on the city's dominant maps, that is, the important sites in the city for the struggle of feminist groups, and enables a discussion on the relationship between the issue of gender and the city.

It is suggested that the maps constructed by subjects and subordinated groups can compose the set of maps used for the planning of the city of Goiânia.

It agrees with the thinking of the geologist Calió (1997) when she affirms that it is only by feminizing the concepts of Planning and the practice of Public Policies that it will be possible to give true dimension to the concept of "citizenship and democracy", that is, only constructing strategies that improve the lives of women and that "take into account their specificity, incorporating them as a priority group in the fight against discrimination" (p.8). (p.8).

The constructed maps will be used by the feminists themselves for spatial analysis of their actions and other groups and women, but it is recommended that they also be present in the construction of public policies for women in the city and employed as tools for the analysis of the urban space that takes into account the singularities and specificities of women's lives. 


\section{Bibliographic References}

ACSELRAD, H. Apresentação. In: ACSELRAD, Henri (org.). Cartografia social e dinâmicas territoriais: marcos para o debate. Rio de Janeiro: Universidade Federal do Rio de Janeiro, Instituto de Pesquisa e Planejamento Urbano e Regional, 2010.

CALIÓ, C. A. Incorporando a Questão de Gênero nos Estudos e no Planejamento Urbano. In: 6º Encontro de Geógrafos de América Latina. Buenos Aires, Argentina, 1997. Anais. Disponível em: $<$ http://observatoriogeograficoamericalatina.org.mx/egal6/Geografiasocioeconomica/Geografiacultural/ 737.pdf > Acesso em 20 de mai de 2016.

FERREIRA, D. C. Diferenciação e Segregação Racial em Goiânia: Representação Cartográfica dos dados de cor ou raça e renda (IBGE, 2010), 2014. Dissertação (mestrado em Geografia) IESA/UFG, Goiânia - GO, 2014.

HAMMES, B. dos S. No Feirão do Chope: Um estudo antropológico sobre intersecções entre marcadores sociais da diferença em um bar na região periferizada de Goiânia, 2015. Dissertação (mestrado em Antropologia Social) PPGAS/UFG, Goiânia - GO, 2015.

HUGGAN, G. Decolonizing the map: post-colonialism, post-struturalism and cartographic connection. Ariel, vol. 20, n. 4, 1989.

IBGE/SIDRA. Sistema IBGE de Recuperação de Recuperação Automática. Rio de Janeiro, 2010.

Disponível em: <http://www.sidra.ibge.gov.br/>. Acesso em 15 de mar. de 2014.

MACHADO, T. C. A cidade das mulheres feministas [manuscrito]: Uma cartografia de Goiânia em perspectiva interseccional e da diferença. 2016. 231 f. Tese (doutorado em Geografia) Universidade Federal de Goiás, Goiânia, 2016.

MARTINELLI, M. As representações gráficas da geografia: os mapas temáticos. 1999. Tese (Livre Docência em Geografia). Faculdade de Filosofia, Letras e Ciências Humanas, Universidade de São Paulo, 1999.

MASSEY, D. Pelo Espaço. Uma Nova Política da Espacialidade. Rio de Janeiro: Bertrand Brasil, 2008.

MOREIRA, R. O Pensamento Geográfico Brasileiro, v. 1: as matrizes clássicas originárias. São Paulo: Contexto, 2008.

Electronic Journal: Time - Technique - Territory, V.7, N.2 (2016), 30:46 ISSN: 2177-4366 
SANTOS, R. E. N. Dos. Ensino de geografia e currículo: questões a partir da lei 10.639. In: Terra Livre. São Paulo, ano 26, v.1, n.34, p. 141-160, jan.-jun.2010.

VILLAÇA, F. Espaço Intra-Urbano no Brasil. São Paulo: Studio Nobel: FAPESP: Lincoln Institute, 2001.

Title: Constructing feminists maps of Goiânia city. Autor: Talita Cabral Machado 